Clinical Images

\title{
Synovial deformant and erosive artropathy in the systemic lupus erythematosus-on purpose of a case
}

\section{Introduction}

A. Female patient NDM 42 years old, White race.

B. Pregnancies 2, Childbirths 0, Abortions 2-spontaneous.

C. Occupation-profession: Cashier accountant.

To the 30 years as she refers, it began with square of rigidity and inflammation of the legs that it improved to the the morning to happen, on the schedule of the noon, as well as breathlessness sensation that went in increment for what she was transferred to the guard of the Hospital Provincial of Cienfuegos where after being carried out Rx of Thorax that shows spill pleural and pericarditis it is entered in Unit of Intensive Cares with the initial diagnosis of a Systemic Lupus Erithematosus, from the beginning treatment was established with high dose of Prednisone, Azatioprina 1 tablate/ 8 hs and it aspirine (125)mg 1 daily tab. Evolutionary improvement and when being given of discharge it took pursuit in consultation Rheumatology of their county during 6 months and then in the Hospital Siblings Ameijeiras in Havana City during 1 year.

It has taken control in external consultation of Rheumatology of their county in a regular way for 10 years, presenting several complications like urinary sepsis to repetition, as well as several times of inferior members vasculitis, maintains pains articular and inflammatory signs mainly in ankles and arch to plant with increase crisis and remissions. She goes to consultation in December of 2016 referring that for six months it presents pain, increase of volume and temperature, swelling and limitation of the movements in the third finger of both hands, and then in the second fingers also in a symmetrical way as well as in both carpos. It is valued in consultation, it is examined being corroborated an inflammatory process of proximals and distals interfalángics articulations in second and third fingers of both hands and limitation of both carpos.

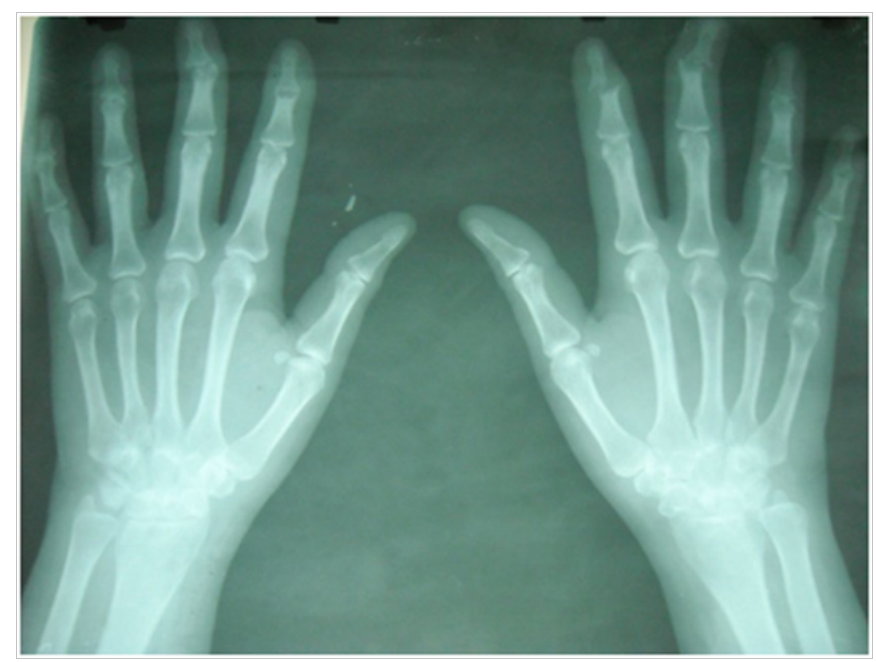

Volume 9 Issue 3 - 2017

\author{
Annia Daisy Hernández Martín,' Ibars \\ Puerto Noda ${ }^{2}$ \\ 'Associate Professor, Heroes de Playa Gir \\ ${ }^{2}$ Heroes de Playa Giron Specialized Outpatient Center, Dr. \\ Gustavo Alderegu
}

Correspondence: Annia Daisy Hernandez Martin, Heroes de Playa Giron Specialized Outpatient Center, Dr. Gustavo Aldereguia Lima General University Hospital, Cienfuegos, Cuba, Email annia.hernandez@gal.sld.cu

Received: July 28, 2017 | Published: November 15, 2017

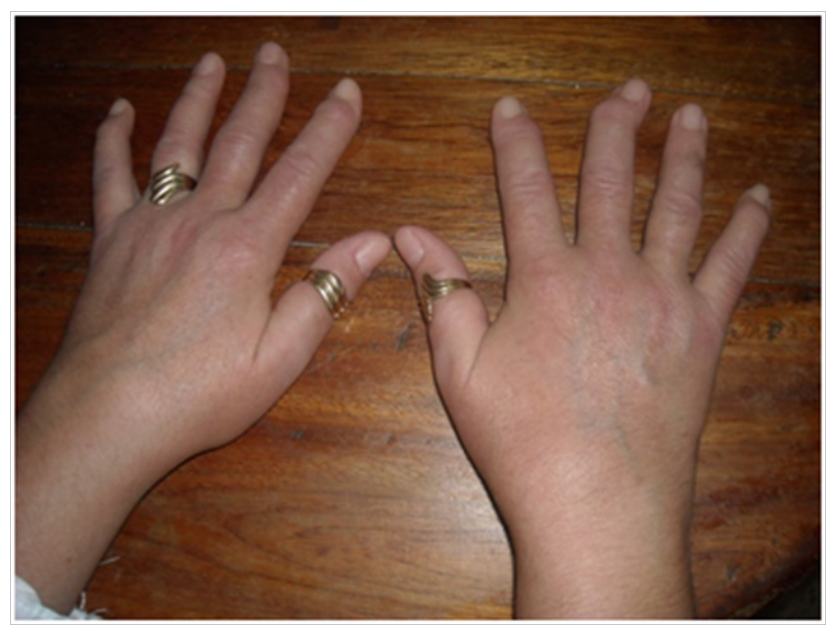

Figure 1\&2 Subluxation and cubital deviation of the $2^{\text {nd }}$ and $3^{\text {rd }}$ fingers of both hands with rupture sinovial and erosion signs in this fingers of the right hand with loss of the structure to articúlate.

She denies fever, don't injure in skin, and she has never referred photosensibility. They are indicated complementary; As results a C Protein is received it reactivates positive and to the $\mathrm{Rx}$ it is appreciated subluxation and cubital deviation of the 2 nd and 3rd fingers of both hands with rupture sinovial and erosion signs in this fingers of the right hand with loss of the structure to articúlate (Figures $1 \& 2$ ). ${ }^{1-9}$

DI: Systemic Lupus Erithematosus.

- Synovial deformant and erosive artropathy in Systemic Lupus Erithematosus.

- Jaccoud's Arthropathy. 


\section{Acknowledgments}

None.

\section{Conflicts of interest}

None.

\section{References}

1. Crow MK. Systemic lupus erythematosus. In: Goldman L, Schafer AI. (Eds.), Goldman's Cecil Medicine. Elsevier Saunders, Philadelphia, USA. 2016;pp.266.

2. Lisnevskaia L, Murphy G, Isenberg D. Systemic lupus erythematosus. Lancet. 2014;384(9957):1878-1888.

3. Ruiz A I, Ugarte A, Cabezas RI, et al. Glucocorticoids and irreversible damage in patients with systemic lupus erythematosus. Rheumatology. 2014;53(8):1470-1476.

4. Tratamiento de las manifestaciones articulares del lupus eritematoso sistémico adultos. segundo y tercer nivel. guía de práctica clínica GPC. Catálogo Maestro de Guías de Práctica Clínica: Instituto Mexicano del seguro social. IMSS-752-15.

5. Spina LMF, Beretta M, Masciocchi M, et al. Clinical and radiological picture of Jaccoud arthropathy in the context of systemic sclerosis. Ann Rheum Dis. 2008;67:728-729.
6. N Spinel P, Montenegro F, Rondón JF, et al. Artropatía de Jaccoud y fibrosis pulmonar en síndrome CREST. Rev Colomb Reumatol. 2010;17:64-68.

7. López LFJ. Artropatía de Jaccoud: algo más que lupus? Semin Fund Esp Reumatol. 2011;12:36-41.

8. Arntfield RT, Jicks CM. Systemic lupus erythematosus and the vasculitides. In: Marx JA, Hockberger RS, Walls RM, (Eds.), Rosen's Emergency Medicine. Elsevier Saunders, Philadelphia, USA. 2014;pp.118.

9. Crow MK. Etiology and pathogenesis of systemic lupus erythematosus. In: Firestein GS, Budd RC, Gabriel SE, McInnes IB, O’Dell JR et al, eds. Kelley's Textbook of Rheumatology. (9th edn), Elsevier Saunders, Philadelphia, USA, p.79. 2013

10. Arntfield RT, Jicks CM. Systemic lupus erythematosus and the vasculitides. In: Marx JA, et al. (Eds.), Rosen's Emergency Medicine, Elsevier Saunders, Philadelphia, USA. 2014;pp.118.

11. Crow MK. Etiology and pathogenesis of systemic lupus erythematosus. In: Firestein GS, et al, (Eds.), Kelley's Textbook of Rheumatology. (9th edn), Elsevier Saunders, Philadelphia, USA, p. 79. 